\title{
Simple preparation of new $N$-aryl- $N$-(3-indolmethyl) acetamides and their spectroscopic analysis
}

\author{
Josué S. Bello, ${ }^{\mathrm{a}}$ Diego F. Amado, ${ }^{\mathrm{a}}{ }_{\text {José }}^{\text {A. Henao, }}{ }^{\mathrm{b}}$ Reinaldo Atencio ${ }^{\mathrm{c}}$ and Vladímir V. Kouznetsov*a \\ ${ }^{a}$ Laboratorio de Química Orgánica y Biomolecular, ${ }^{b}$ Grupo de Investigación en Química Estructural, CIBIMOL, \\ Escuela de Química, Universidad Industrial de Santander, A.A. 678, Bucaramanga, Colombia. \\ ${ }^{c}$ Laboratorio de Síntesis y Caracterización de Nuevos Materiales, Centro de Química, \\ Instituto Venezolano de Investigaciones Científicas, Caracas, Venezuela. \\ *kouznet@uis.edu.co; jahenao@uis.edu.co
}

Received: 05-11-2009; Accepted: 30-12-2009

\begin{abstract}
Objectives. To prepare new indolic molecules and characterize them by spectroscopic methods. Materials and methods: All reagents were purchased from Aldrich, commercial grade. The purity of the products and the composition of the reaction mixtures were monitored by thin layer chromatography over Silufol $\mathrm{UV}_{254} 0.25 \mathrm{~mm}$-thick chromatoplates. Product isolation and purification were performed by column chromatography $\left(\mathrm{SiO}_{2}\right)$, using ethyl acetate-petroleum ether mixtures as eluents. Results. The synthesis of new $N$-aryl- $N$-(3indolmethyl) acetamides based on first step iminization reaction of indol-3-carbaldehyde is accomplished. The structures of the C-3 substituted indoles were confirmed by ${ }^{1} \mathrm{H}-\mathrm{NMR}$ and ${ }^{13} \mathrm{C}-\mathrm{NMR}$ studies supported by inverse-detected 2D NMR experiments and also through monocrystal X-ray diffraction. Conclusions. An efficient, economic, and fast synthetic route was designed to the construction of the $N$-aryl- $N$-(3-indolmethyl) acetamides, structural analogues of some alkaloids.
\end{abstract}

Key words: indole, acetamides, iminization

\section{Resumen}

Preparación sencilla de nuevas $\mathrm{N}$-aril- $\mathrm{N}$-(3-indolmetil) acetamidas y su análisis espectroscópico. Objetivos: Preparar nuevas moléculas indólicas y caracterizarlas por los métodos espectroscópicos. Materiales y métodos. Todos los reactivos fueron adquiridos de Aldrich, de grado comercial. La pureza de los productos y composición de las mezclas de reacción fueron monitoreadas por la cromatografía en capa delgada, Silufol $\mathrm{UV}_{254} 0.25 \mathrm{~mm}$-grosor de cromatoplacas. El aislamiento y purificación de los productos fueron realizados por la cromatografía en columna $\left(\mathrm{SiO}_{2}\right)$, usando mezclas de acetato de etilo y éter de petróleo como eluentes. Resultados. Se ha realizado la síntesis de nuevas $N$-aril- $N$-(3-indolmetil) acetamidas, basada en la reacción de iminización del indol-3-carbaldehído. Las estructuras de los indoles $\mathrm{C}-3$ sustituidos fueron confirmadas por estudios de ${ }^{1} \mathrm{H},{ }^{13} \mathrm{C}-\mathrm{RMN}$, experimentos de 2D RMN y también por difracción monocristal de Rayos X. Conclusiones. Se ha diseñado una nueva ruta de síntesis eficiente, económica y rápida para la construcción de las $N$-aril- $N$ (3-indolmetil) acetamidas, análogos estructurales de diversos alcaloides.

Palabras clave: indol, acetamidas, iminización 


\section{Resumo}

Preparação simples de novas $N$-aril- $N$-(3-indolmetil)acetamidas e sua análise espectroscópica. Objetivos. Preparar novas moléculas indólicas e caracterizar-las através de métodos espectroscópicos. Materiais e métodos. Todos os reagentes foram obtidos de Aldrich, de tipo comercial. A pureza dos produtos e a composição das misturas de reação foram monitoradas por cromatografia em camada fina, Silufol $\mathrm{UV}_{254} 0,25 \mathrm{~mm}$ de espessura das cromatoplacas. O isolamento e a purificação dos produtos foram feitos através de cromatografia em coluna ( $\mathrm{SiO} 2)$, utilizando misturas de acetato de etila e éter de petróleo como eluente. Resultados. Realizou-se a síntese de novas $N$-aril$N$-(3-indolmetil)acetamidas, baseada na reação de iminización do indol-3-carbaldeído. As estruturas dos indóis C-3 substituídos foram confirmadas por estudos de ${ }^{1} \mathrm{H},{ }^{13} \mathrm{C}$-RMN, experimentos de 2D RMN e também por difração monocristal dos Rayos X. Conclusões. Desenhou-se una nova rota de síntese eficiente, econômica e rápida para a construção das $N$-aril- $N$-(3-indolmetil) acetamidas, análogos estruturais de vários alcalóides.

Palavras-chave: indol, acetamidas, iminização

\section{Introduction}

The research of the indol chemistry has been and still is one of the most active areas of heterocyclic chemistry. In recent years, much interest has been attracted to the preparation of substituted indoles due to their numerous biologically significant activities. ${ }^{1}$ The 3-indolylmethanamine derivatives $\mathbf{1}$ were the important intermediates of the natural and natural-like products, such as hydro- $\gamma$ carboline and pyrido[4,3- $b]$ indole derivatives. ${ }^{2,3}$ This 3indolyl methanamine motif is also embedded in numerous indole alkaloids from simple alkaloid gramine $\mathbf{2}$ to complex aspidospermine alkaloid $\mathbf{3}^{4,5}$ (Figure 1).
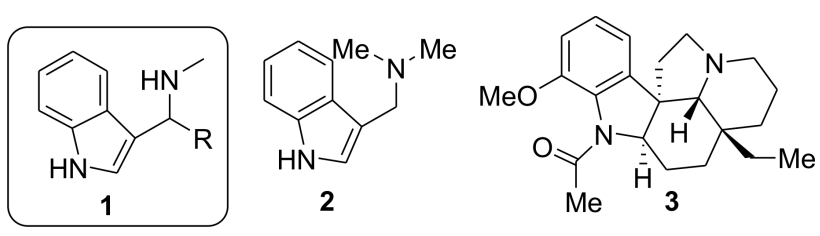

Figure 1. Relevant natural alkaloids derived from the 3indolylmethanamine system.

As a result of their biological and synthetic importance, a variety of methods have been reported for the preparation of 3-substituted indoles, using indol or 3-indolcarboxyaldehyde as starting materials. Generally, the Mannich reaction $^{6,7}$ and the catalyzed Friedel-Crafts alkylation reactions of indoles ${ }^{8-11}$ are considered as a powerful carboncarbon bond process to afford the 3-indolylmethanamine derivatives $\mathbf{1}$. However, another synthetic route to these compounds by using 3-indolcarboxyaldehyde via its imino derivatives formation is valid. This route has been employed by our laboratory, which recently started an own medicinal program directed to small molecules for drug delivery. We were particularly interested in 3-indolylmethanamine derivatives molecules that could serve as useful precursors to many drug-like indolic compounds in our quest for compounds with antiparasitic properties..$^{12-14}$ To the best of our knowledge, a simple preparation of new (3indolmethyl) acetamide and (1-acetylindolmethyl-3) acetamide regulating only a solvent nature has not been described. The results of our investigation on preparation, spectral and structural characterization of new two acetamides based on 3-indolyl methanamine motif are reported in this work.

\section{Materials and methods}

All reagents were purchased from Aldrich, commercial grade. The purity of the products and the composition of the reaction mixtures were monitored by thin layer chromatography over Silufol $\mathrm{UV}_{254} 0.25 \mathrm{~mm}$-thick chromatoplates. Product isolation and purification were performed by column chromatography over silica gel, using ethyl acetate-petroleum ether mixtures as eluents. The IR spectra were measured with a Lumex infralum FT-02 spectrophotometer in $\mathrm{KBr}$. The ${ }^{1} \mathrm{H}-\mathrm{NMR}$ spectra were acquired Bruker Advance AM-400 spectrometers using $\mathrm{CDCl}_{3}$ as a solvent and TMS as internal reference. The mass spectra were obtained on an HP 5890A series II gas chromatograph interfaced to an HP 5972 mass selective detector that used electron impact ionization $(70 \mathrm{eV})$. Xray diffraction single-crystal technique with an AFC7S four circle diffractometer was used. The data acquisition was made to $293 \mathrm{~K}$ of temperature with $\operatorname{MoK} \alpha(\lambda=0.71073 \AA)$ radiation and a measurement range between 1 and $25^{\circ}$ to theta $(\theta)$. The structure elucidation and the refinement were made with the software Shelxs-97 and Shelx1-97, respectively. 
$N$-(3-Indolyden)-2-cyanoaniline (6)

A mixture of the indol-3-carbaldehyde 4 (1.18 g, 8.14 $\mathrm{mmol})$, the 2-cyanoaniline $5(1.15 \mathrm{~g}, 9.77 \mathrm{mmol})$, and the glacial AcOH (7.40 mL) was prepared in dry toluene (50 $\mathrm{mL})$. The reaction mixture was stirred and refluxed for 8 hours with a Dean-Stark trap. Once the reaction mixture was allowed to room temperature, the precipitated solid was filtered and washed with petroleum ether. Then, it was dried to vacuum to obtain $1.90 \mathrm{~g}(7.76 \mathrm{mmol}, 95 \%)$ of clean white and stable solid product $6 . \mathrm{R}_{\mathrm{f}} 0.44(2: 1$ petroleum ether/ethyl acetate). Mp. 207-208 ${ }^{\circ} \mathrm{C}$. Anal. calcd for $\mathrm{C}_{16} \mathrm{H}_{11} \mathrm{~N}_{3}$ : C, 78.35; H, 4.52; N, 17.13. $\mathrm{M}=245.10$. Found: C, 78.16; H, 4.67; N, 17.18. GC-MS: $R_{\mathrm{t}}=29.34$ min; $m / z$ (\%): $245\left(\mathrm{M}^{+}, 100\right), 218$ (12), 190 (8), 142 (18), 116 (19), 89 (14). IR (KBr): $3386 v_{(\mathrm{NH})}, 2222 \mathrm{v}_{(\mathrm{CN})}, 1612$ $\mathrm{v}_{(\mathrm{C}=\mathrm{N})}, 1423 \mathrm{v}_{(\mathrm{C}=\mathrm{C})}, 1338 \mathrm{v}_{(\mathrm{C}-\mathrm{N})} \mathrm{cm}^{-1}$.

\section{2- $N$-[(1H-Indol-3-ylmethyl]aminobenzonitrile (7)}

To an ethanol solution $(100 \mathrm{~mL})$ of $2.00 \mathrm{~g}(8.16 \mathrm{mmol})$ of the $N$-(3-indolyden)-2-cyanoaniline 6, $1.54 \mathrm{~g}$ (40.7 mmol) of $\mathrm{NaBH}_{4}$ in small proportions was slowly added to the reaction mixture. After the addition of the reductive agent, the reaction mixture was refluxed for $90 \mathrm{~min}$. The reaction mixture was allowed to room temperature and diluted with $100 \mathrm{~mL}$ of distilled water to obtain the white precipitated solid, which was filtered and vacuum dried to obtain 1.40 $\mathrm{g}(5.97 \mathrm{mmol}, 70 \%)$ of the product $7 . \mathrm{R}_{\mathrm{f}} 0.43$ (3:1 petroleum ether/ethyl acetate). Mp. $148-149{ }^{\circ} \mathrm{C}$. Anal. calcd for $\mathrm{C}_{16} \mathrm{H}_{13} \mathrm{~N}_{3}$ : C, 77.71; H, 5.30; N, 16.99. $\mathrm{M}=247.11$. Found: C, 77.53; H, 5.57; N, 16.90. GC-MS: $R_{\mathrm{t}}=26.42 \mathrm{~min} ; \mathrm{m} / z$ (\%): $247\left(\mathrm{M}^{+\cdot}, 7\right), 207$ (8), 149 (9), 130 (100), 118 (36), 102 (23), 91 (18). IR (KBr): $3402 \mathrm{v}_{(\mathrm{NH})}, 3352 \mathrm{v}_{(\mathrm{NH}-\text { indol })}, 2218$ $\mathrm{v}_{(\mathrm{CN})}, 1605 \mathrm{v}_{(\mathrm{NH})}, 1419 \mathrm{v}_{(\mathrm{C}=\mathrm{C})}, 1335 \mathrm{v}_{(\mathrm{C}-\mathrm{N})} \mathrm{cm}^{-1} ;{ }^{1} \mathrm{H}$ NMR (400 $\mathrm{MHz}): \delta 8.12(1 \mathrm{H}$, br.s, H-N), $7.63(1 \mathrm{H}, \mathrm{d}, J=7.8 \mathrm{~Hz}, 4-$ $\left.\mathrm{H}_{\text {indol }}\right), 7.22\left(1 \mathrm{H}, \mathrm{dd}, J=8.8,6.1 \mathrm{~Hz}, 5^{\prime}-\mathrm{H}_{\mathrm{Ar}}\right), 7.40-7.36(3 \mathrm{H}$, $\left.\mathrm{m}, 2,5,6-\mathrm{H}_{\text {indol }}\right), 7.17-7.3\left(2 \mathrm{H}, \mathrm{m}, 7-\mathrm{H}_{\text {indol }}, 3^{\prime}-\mathrm{H}_{\mathrm{Ar}}\right), 6.81(1 \mathrm{H}$, $\left.\mathrm{d}, J=8.3 \mathrm{~Hz}, 6^{\prime}-\mathrm{H}_{\mathrm{Ar}}\right), 6.68\left(1 \mathrm{H}, \mathrm{t}, J=7.5 \mathrm{~Hz}, 4^{\prime}-\mathrm{H}_{\mathrm{Ar}}\right), 4.84$ $\left(1 \mathrm{H}\right.$, br.s, H-N), $4.56\left(2 \mathrm{H}, \mathrm{d}, J=4.9 \mathrm{~Hz},-\mathrm{CH}_{2}\right) \mathrm{ppm} .{ }^{13} \mathrm{C}$ NMR (100 MHz): $\delta$ 150.2, 136.3, $134.6(+), 132.3(+)$, $126.5,122.7(+), 122.5(+), 119.9(+) 118.6(+), 117.1,116.1$ $(+), 112.3,111.3(+), 110.9(+), 95.6,39.4(-)$ ppm.

$N$-(2-Cyanophenyl)- $N$-(1H-indol-3-ylmethyl)acetamide (8)

A mixture of the amine $7(1.00 \mathrm{~g}, 4.05 \mathrm{mmol})$, acetic anhydride (1.65 g, $16.20 \mathrm{mmol})$, and $\mathrm{Et}_{3} \mathrm{~N}$ (1.22 g, 12.10 $\mathrm{mmol})$ was prepared in dry toluene $(20 \mathrm{~mL})$. The reaction mixture was heated at $70^{\circ} \mathrm{C}$ for 3 hours. The reaction mixture was allowed to reach room temperature and was treated with $30 \mathrm{~mL}$ of aqueous $\mathrm{Na}_{2} \mathrm{CO}_{3}$ and extracted with ethyl acetate $(3 \times 30 \mathrm{~mL})$. The organic layer was dried over $\mathrm{Na}_{2} \mathrm{SO}_{4}$ and then concentrated in vacuum. The crude product was purified through silica gel preparative chromatography with petroleum ether / ethyl acetate (10:1) to obtain a white solid acetamide $80.50 \mathrm{~g}$ (1.73 mmol, 43\%). $\mathrm{R}_{\mathrm{f}} 0.43$ (3:1 petroleum ether/ethyl acetate). Mp. $144-145^{\circ} \mathrm{C}$. Anal. calcd for $\mathrm{C}_{18} \mathrm{H}_{15} \mathrm{~N}_{3} \mathrm{O}: \mathrm{C}, 74.72 ; \mathrm{H}, 5.23 ; \mathrm{N}, 14.52 . \mathrm{M}=$ 289.33. Found: C, 74.64; H, 5.49; N, 14.37. GC-MS: $R_{\mathrm{t}}=$ $27.94 \mathrm{~min} ; \mathrm{m} / \mathrm{z}(\%): 289\left(\mathrm{M}^{+}, 12\right), 246$ (3), 190 (8), 172 (23), 130 (100), 118 (22), 102 (11), 77 (9). IR (KBr): 3342 $\mathrm{v}_{(\mathrm{NH})}, 2211 \mathrm{v}_{(\mathrm{C}-\mathrm{N})}, 1701 \mathrm{v}_{(\mathrm{NC}=\mathrm{O})}, 1674 \mathrm{v}_{(\mathrm{N}-\mathrm{H})}, 1450 \mathrm{v}_{(\mathrm{C}=\mathrm{C})}$, $1371 \mathrm{v}_{(\mathrm{C}-\mathrm{N})} \mathrm{cm}^{-1} ;{ }^{1} \mathrm{H}$ NMR (400 MHz): $\delta 8.44(1 \mathrm{H}, \mathrm{d}, J=8.0$ $\left.\mathrm{Hz}, 6^{\prime}-\mathrm{H}_{\mathrm{Ar}}\right), 7.57\left(1 \mathrm{H}, \mathrm{ddd}, J=7.7,7.3,1.1 \mathrm{~Hz}, 4-\mathrm{H}_{\text {indol }}\right)$, 7.40-7.35 (4H, m, 5,7- $\left.\mathrm{H}_{\text {indol }}, 4^{\prime}, 5^{\prime}-\mathrm{H}_{\mathrm{Ar}}\right), 7.31$ (ddd, $J=7.7$, 7.3, 1.1 Hz, 6- $\left.\mathrm{H}_{\text {indol }}\right), 6.76-6.71\left(2 \mathrm{H}, \mathrm{m}, 2-\mathrm{H}_{\text {indol }}, 3^{\prime}-\mathrm{H}_{\mathrm{Ar}}\right)$, 4.95 (1H, br.s, H-N), 4.55 (2H, s, $\left.\mathrm{CH}_{2}\right), 2.58(3 \mathrm{H}, \mathrm{s}, \mathrm{Me})$ ppm. ${ }^{13} \mathrm{C}$ NMR (100 MHz): $\delta$ 168.6, 149.2, 136.2, 134.1 $(+), 132.8(+), 128.9,125.7(+), 123.8(+), 123.0(+), 118.9$ $(+), 118.7(+), 117.7,117.2(+), 116.4,111.5(+), 96.2,39.3$ $(+), 23.9(-)$ ppm.

$N$-(1-Acethyl-1H-indol-3-ylmethyl)- $N$-(2-cyanophenyl) acetamide (9)

A mixture of the amine $7(0.50 \mathrm{~g}, 2.02 \mathrm{mmol})$, acetic anhydride (10.80 g, $98 \mathrm{mmol})$, and $\mathrm{Et}_{3} \mathrm{~N}(0.44 \mathrm{~g}, 4.30 \mathrm{mmol})$ was heated at $100^{\circ} \mathrm{C}$ for 3 hours. Then, the reaction mixture was allowed to reach room temperature and then treated with $50 \mathrm{~mL}$ of aqueous $\mathrm{NaOH}$ and extracted with ethyl acetate $(3 \times 30 \mathrm{~mL})$. The organic layer was dried over $\mathrm{Na}_{2} \mathrm{SO}_{4}$ and later dried in vacuum. Silica gel preparative chromatography (petroleum ether / ethyl acetate, 2:1) of the crude product afforded diacetamide $9(0.53 \mathrm{~g}, 80 \%)$ as a white and stable solid. $\mathrm{R}_{\mathrm{f}} 0.50$ (petroleum ether/ethyl acetate, $1: 1)$. Mp. $124-125^{\circ} \mathrm{C}$. Anal. Calcd for $\mathrm{C}_{20} \mathrm{H}_{17} \mathrm{~N}_{3} \mathrm{O}_{2}$ : C, 72.49; H, 5.17; N, 12.68. $\mathrm{M}=331.13$. Found: C, 72.23; H, 5.33; N, 12.35. GC-MS: $R_{\mathrm{t}}=28.52 \mathrm{~min} ; \mathrm{m} / \mathrm{z}(\%): 331$ $\left(\mathrm{M}^{+\cdot}, 12\right), 289(7), 246(7), 172(9), 130(100), 118(10), 102$ (7), 77 (7). IR (KBr): $2229 v_{(\mathrm{CN})}, 1704 v_{(\mathrm{NC}=0)}, 1654 v_{(\mathrm{NC}=0)}$, $1658 \mathrm{v}_{(\mathrm{N}-\mathrm{H})}, 1454 \mathrm{v}_{(\mathrm{C}=\mathrm{C})}, 1348 \mathrm{v}_{(\mathrm{C}-\mathrm{N})} \mathrm{cm}^{-1} .{ }^{1} \mathrm{H}$ NMR $(400$ $\mathrm{MHz}): \delta 7.87\left(1 \mathrm{H}, \mathrm{d}, J=8.0 \mathrm{~Hz}, 7-\mathrm{H}_{\text {indol }}\right), 7.94(1 \mathrm{H}, \mathrm{dd}, J=$ $\left.7.7 \mathrm{~Hz}, 4-\mathrm{H}_{\text {indol }}\right), 7.78-7.69\left(6 \mathrm{H}, \mathrm{m}, 3^{\prime}, 4^{\prime}, 5^{\prime}-\mathrm{H}_{\mathrm{Ar}}\right), 7.44(2 \mathrm{H}$, $\left.\mathrm{m}, 6-\mathrm{H}_{\text {indol }}\right), 7.36\left(1 \mathrm{H}, \mathrm{s}, 2-\mathrm{H}_{\text {indol }}\right), 6.84-6.71\left(2 \mathrm{H}, \mathrm{m}, 5-\mathrm{H}_{\text {indol }}\right.$, $\left.3^{\prime}-\mathrm{H}_{\mathrm{Ar}}\right), 5.10\left(2 \mathrm{H}, \mathrm{s}, \mathrm{CH}_{2}\right), 2.66(3 \mathrm{H}, \mathrm{s}, \mathrm{Me}), 2.03(3 \mathrm{H}, \mathrm{s}$, Me) ppm. ${ }^{13} \mathrm{C}$ NMR (100 MHz): $\delta 169.4,168.5,144.7$, 135.6, 134.4(+), 133.9, 130.3 (+), 129.3, $128.8(+), 125.4$ $(+), 123.7(+), 118.9(+), 117.3,116.5(+), 115.8,113.1$, $42.8(-), 23.9(+), 22.4(+)$ ppm.

\section{Results and discussion}

Aldimines are valuable starting materials not only for different $\mathrm{N}$-containing heterocycles but also for diverse secondary heteroaromatic amines, ${ }^{15}$ which represent good 
candidates for bio-screening with diverse types of activities. ${ }^{16,17}$ Thus, the $\mathrm{N}$-aryl imine $\mathbf{6}$, the main starting material in this research, was prepared from commercially available 3-indolaldehyde (4) and 2-cyanoaniline (5), according to published methods. ${ }^{18,19}$ This aldimine was obtained in $95 \%$ as a white and stable solid. Since the reduction of aldimines with an excess of $\mathrm{NaBH}_{4}$ in methanol is still the reaction of choice to produce the secondary amines in reasonably good yield, we employed this method in our work. Thus, $N$-(2-cyanophenyl)- $N$-(3indolylmethyl)amine (7) was prepared as a white solid in $70 \%$ yields after purification through recrystallization (Figure 2). Since this amine has interesting structural elements to use in the synthesis of different indolic heterocycles, we studied its acetylation reaction with acetic anhydride. Firstly, to a stirred solution of amine 7 in toluene as a solvent and in the presence of $\mathrm{Et}_{3} \mathrm{~N}$, excessive acetic anhydride is added and refluxed during the appropriate period of time to allow the $\mathrm{N}$-(2-cyanophenyl)- $\mathrm{N}$-(3indolmethyl)acetamide (8) synthesis in acceptable yields (45-50\%). Then, the acetylating reaction between the amine and excess acetic anhydride in the presence of $\mathrm{Et}_{3} \mathrm{~N}$ at $100{ }^{\circ} \mathrm{C}$ without an organic solvent (toluene) was performed. After usual workup, diacetylated indole 9 was obtained in good yields (80-85 \%). Therefore, a simple change in the reaction conditions could afford different acetamides based on the 3-indolyl methanamine motif (Figure 2). This developed selective process represents a good protocol for the synthetic organic chemistry, especially within those processes requiring a particular position protection.
The structures of the C-3 substituted indoles 7-9 were confirmed on the basis of analytical and spectral data and were supported by inverse-detected 2D NMR experiments. The compound 7 IR spectrum characteristic absorption bands were observed at 3402 and $3352 \mathrm{~cm}^{-1}$, assignable to tension vibrations $\mathrm{CH}_{2}-\mathrm{N}-\mathrm{H}$ and $\mathrm{N}-\mathrm{H}_{\text {indol }}$ respectively. Its ${ }^{1} \mathrm{H}$ NMR spectrum displays a duplet at $\mathrm{d} 4.56 \mathrm{ppm}(J=4.9$ $\mathrm{Hz})$ ppm corresponding to two protons coupling with the neighbor N-H proton (br. s, $4.84 \mathrm{ppm}$ ), which suggest the presence of the methylenic unit linked to the $\mathrm{N}-\mathrm{H}$ function. The peaks at d 7.17-7.3 (H-7), 7.36-7.40 (H-5, H-2, H-6), and 7.63 (H-4) ppm showed the presence of aromatic protons of the indole moiety. The ${ }^{13} \mathrm{C}$ NMR spectra, also showed all expected characteristic peaks at d $39.4\left(\mathrm{CH}_{2}\right)$, $117(\mathrm{CN})$, and 95.6-150.2 (aromatic carbons).

The compound $\mathbf{8}$ gave a molecular ion peak $\mathrm{M}^{+}$, at $m / z 289$, suggesting the molecular formula $\mathrm{C}_{18} \mathrm{H}_{15} \mathrm{~N}_{3} \mathrm{O}$, and indicating the acetyl group coupling with 7 . The acetamide 8 displayed characteristic infrared absorption bands with a single amine absorption band at $3342 \mathrm{~cm}^{-1}$ and with a carbonyl signal at $1701 \mathrm{~cm}^{-1}$ suggesting the acetylation reaction involvement of the $\mathrm{CH}_{2}-\mathrm{N}$; this is the band appearing at high wave number of the corresponding $\mathrm{N}-\mathrm{H}_{\text {indol }}$ vibration tension in the IR spectrum. Its ${ }^{1} \mathrm{H}$ NMR spectra analysis showed a singlet at $2.58 \mathrm{ppm}$ corresponding to three protons which belong to the acetyl group and another singlet at $4.55 \mathrm{ppm}$ due to the presence of the methylenic $3-\mathrm{CH}_{2}-\mathrm{N}$ indolic protons. This signal's multiplicity is explained by assuming the proton $\mathrm{N}-\mathrm{H}$ next to it, substituted now for the acetyl group, which leaves no possibility to $\mathrm{H}, \mathrm{H}$ coupling, while it does happen<smiles>CCN(CC)C(=O)c1ccccc1N(Cc1c[nH]c2ccccc12)Cc1c[nH]c2ccccc12</smiles>

Figure 2. Preparation of $N$-aryl- $N$-(3-indolmethyl)acetamides. 
with the amine 7. The ${ }^{13} \mathrm{C}$ NMR spectrum of the acetamide 8 displayed characteristic carbonyl signal at $168 \mathrm{ppm}$, this is strong evidence to an acetyl group bonded to the molecule; in addition to a signal at 39.3 and $23.9 \mathrm{ppm}$, showing the presence of $\mathrm{CH}_{2}$ and $\mathrm{CH}_{3}$ in the molecule. Introduction of an acetyl group into the molecule affects the H-6' chemical shift from the aromatic moiety; this is $116 \mathrm{ppm}$ to the compound 7 an $123 \mathrm{ppm}$ to the acetamide $\mathbf{8}$. The signal at $39.3 \mathrm{ppm}$ for $\mathrm{CH}_{2}-\mathrm{N}$ has been distinguished on the basis of the DEPT-135 experiment. On the basis of these spectral studies, compound $\mathbf{8}$ was characterized as the $N$-(2cyanophenyl)- $N$-(1H-indol-3-ylmethyl)acetamide.

The new compound 9 gave a molecular ion peak at $\mathrm{m} / \mathrm{z}$ 331 , corresponding to the molecular formula $\mathrm{C}_{20} \mathrm{H}_{17} \mathrm{~N}_{3} \mathrm{O}_{2}$ as indicated by its EI-MS. The loss of 43 units (one acetyl group) generates the same mass spectrum as the acetamide 8. The IR spectrum shows bands at 1704 and $1654 \mathrm{~cm}^{-1}$, assignable to two carbonyl groups. The N-H absorption bands were not observed in the region of 3300-3400 $\mathrm{cm}^{-1}$. The ${ }^{1} \mathrm{H}$ NMR spectrum showed, as expected, two singlets at d 22.4 and 23.9 ppm, which integrated three protons each. To the methylenic protons case, they appeared to be diasterotopic resonating at the high field frequencies d 4.75 and $5.46 \mathrm{ppm}$ with a coupling constant $J=15 \mathrm{~Hz}$, usual constant value to a germinal coupling. Of course, the aromatic protons were also assigned. The ${ }^{13} \mathrm{C}$ NMR spectrum showed all expected characteristic peaks at d 169.4 (ArN-CO-), $168.5\left(\mathrm{Ar}_{\text {indol }} \mathrm{N}-\mathrm{CO}-\right) \mathrm{ppm}$, in addition to a signal at $\delta$ $117.3 \mathrm{ppm}$ showing the presence of $\mathrm{TC} \equiv \mathrm{N}$ in the molecule. Besides, methyl carbons at $23.9\left(\mathrm{Ar}_{\text {indol }} \mathrm{NCO}-\right.$ $\mathrm{CH}_{3}$ ) and 22.4 (ArNCO- $\mathrm{CH}_{3}$ ) ppm and the methylene carbon at d $42.8 \mathrm{ppm}$ were also displayed in the ${ }^{13} \mathrm{C}$ NMR.

With respect to the characterization of the diacetamide 9, through X-ray diffraction, the monoclinic system was determined with the compound crystallized at $25^{\circ} \mathrm{C}$ from heptane-ethyl acetate (2:1) (Figure 3).

The crystallized material has the following cell constants: $\mathrm{a}=11.1184(19) \AA, \mathrm{b}=8.0048(13) \AA, \mathrm{c}=20.534(4) \AA$, and space group $\mathrm{P} 2 / \mathrm{n}$ (Table 1 ), possessing the different bond lengths of the molecule constituent atoms was also extracted with this technique (Table 2).

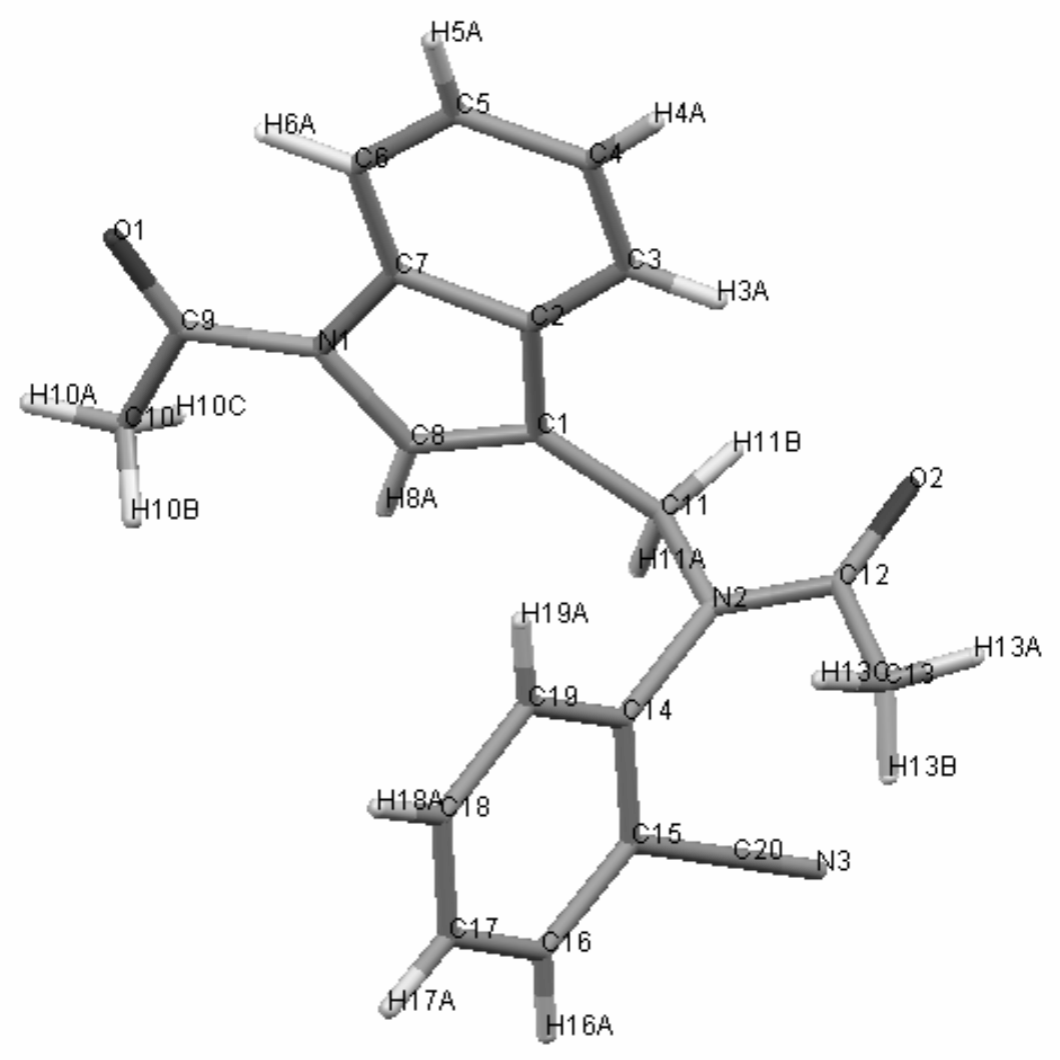

Figure 3. X-Ray structure of the diacetamide 9 
Table 1. Crystal data and structure refinement parameters of diacetamide 9

\section{Crystal morphology}

Chemical formula

Molecular weight

Crystal system

Space group

Cells constants

Volume

Absorption coefficient

Density

Temperature

Range for data collection

Index range

$\mathrm{R}$

Rw

Threshold expression

Diffraction radiation

$\lambda$

\section{White parallelepiped}

$\mathrm{C}_{20} \mathrm{H}_{17} \mathrm{~N}_{3} \mathrm{O}_{2}$

331.13

Monoclinic

$\mathrm{P} 21 / \mathrm{n}$

$\mathrm{a}=11.1184(19) \AA, \mathrm{b}=8.0048(13) \AA$ and $\mathrm{c}=$

20.534(4) $\AA, \alpha=90^{\circ}, \beta=94.281(4), \gamma=90^{\circ}$

$1822.4(5) \AA^{3}$

$0.082 \mathrm{~mm}^{-1}$

$1.244 \mathrm{Mg} \mathrm{m}^{-3}$

293(2) K

1.99- 28.09

$\mathrm{h}=-13 \rightarrow 28, \mathrm{k}=-9 \rightarrow 7, \mathrm{l}=-23 \rightarrow 23$

0.0567

0.0582

$>2 \operatorname{sigma}(\mathrm{I})$

$\mathrm{M}_{\mathrm{o}} \mathrm{K} \alpha$

$0.71070 \AA$
From these data, the different bond lengths of the two amide bonds present within the structure were as expected. Even knowing the double bond character of the amide bonds, in this case, the amide bond distance between the aliphatic nitrogen $\mathrm{N} 2$ and $\mathrm{C} 12$ is $1.364 \AA$, while the distance between the aromatic nitrogen $\mathrm{N} 1$ and $\mathrm{C} 9$ is $1.388 \AA$. These data correspond with the idea that the amide bond N2-C12 is shorter because of the electron withdrawing inductive effect from the $\alpha$-cyanophenyl substituent and the possibility of the nitrogen non-shared electrons to be delocalized on the amide bond through a mesomeric effect giving this bond a stronger double bond character.

From these data, the different bond lengths of the two amide bonds present within the structure were as expected. Even knowing the double bond character of the amide bonds, in this case, the amide bond distance between the aliphatic nitrogen N2 and C12 is $1.364 \AA$, while the distance between the aromatic nitrogen N1 and C9 is $1.388 \AA$. These data correspond with the idea that the amide bond N2-C12 is shorter because of the electron withdrawing inductive effect from the $\alpha$-cyanophenyl substituent and the possibility of the nitrogen non-shared electrons to be delocalized on the amide bond through a mesomeric effect giving this bond a stronger double bond character.

On the other hand, the amide bond N1-C9 is longer because the nitrogen non-shared electrons are involved with the aromatic system and they are not so available to be delocalized on the amide bond giving it less double bond character. 
Table 2. Bond lengths between the molecule atoms of diamide 9.

\begin{tabular}{|c|c|c|c|}
\hline Number & Atom 1 & Atom 2 & Length $(\AA)$ \\
\hline 1 & O1 & C9 & 1.220 \\
\hline 2 & $\mathrm{O} 2$ & $\mathrm{C} 12$ & 1.221 \\
\hline 3 & N1 & $\mathrm{C} 7$ & 1.415 \\
\hline 4 & N1 & $\mathrm{C} 8$ & 1.405 \\
\hline 5 & $\mathrm{~N} 1$ & C9 & 1.388 \\
\hline 6 & $\mathrm{~N} 2$ & $\mathrm{C} 11$ & 1.473 \\
\hline 7 & $\mathrm{~N} 2$ & $\mathrm{C} 12$ & 1.364 \\
\hline 8 & $\mathrm{~N} 2$ & $\mathrm{C} 14$ & 1.430 \\
\hline 9 & N3 & $\mathrm{C} 20$ & 1.143 \\
\hline 10 & $\mathrm{C} 1$ & $\mathrm{C} 2$ & 1.449 \\
\hline 11 & $\mathrm{C} 1$ & $\mathrm{C} 8$ & 1.338 \\
\hline 12 & $\mathrm{C} 1$ & $\mathrm{C} 11$ & 1.489 \\
\hline 13 & $\mathrm{C} 2$ & $\mathrm{C} 3$ & 1.385 \\
\hline 14 & $\mathrm{C} 2$ & $\mathrm{C} 7$ & 1.404 \\
\hline 15 & $\mathrm{C} 3$ & $\mathrm{H} 3 \mathrm{~A}$ & 0.931 \\
\hline 16 & $\mathrm{C} 3$ & $\mathrm{C} 4$ & 1.371 \\
\hline 17 & $\mathrm{C} 4$ & $\mathrm{H} 4 \mathrm{~A}$ & 0.929 \\
\hline 18 & $\mathrm{C} 4$ & C5 & 1.378 \\
\hline 19 & $\mathrm{C} 5$ & $\mathrm{H} 5 \mathrm{~A}$ & 0.931 \\
\hline 20 & $\mathrm{C} 5$ & C6 & 1.377 \\
\hline 21 & C6 & H6A & 0.930 \\
\hline 22 & C6 & $\mathrm{C} 7$ & 1.384 \\
\hline 23 & $\mathrm{C} 8$ & H8A & 0.930 \\
\hline 24 & C9 & $\mathrm{C} 10$ & 1.481 \\
\hline 25 & $\mathrm{C} 10$ & $\mathrm{H} 10 \mathrm{~A}$ & 0.960 \\
\hline 26 & $\mathrm{C} 10$ & H10B & 0.961 \\
\hline 27 & $\mathrm{C} 10$ & $\mathrm{H} 10 \mathrm{C}$ & 0.961 \\
\hline 28 & $\mathrm{C} 11$ & H11A & 0.971 \\
\hline 29 & $\mathrm{C} 11$ & H11B & 0.971 \\
\hline 30 & $\mathrm{C} 12$ & $\mathrm{C} 13$ & 1.497 \\
\hline 31 & $\mathrm{C} 13$ & H13A & 0.961 \\
\hline 32 & $\mathrm{C} 13$ & H13B & 0.960 \\
\hline 33 & $\mathrm{C} 13$ & $\mathrm{H} 13 \mathrm{C}$ & 0.960 \\
\hline 34 & $\mathrm{C} 14$ & $\mathrm{C} 15$ & 1.387 \\
\hline 35 & $\mathrm{C} 14$ & $\mathrm{C} 19$ & 1.364 \\
\hline 36 & $\mathrm{C} 15$ & $\mathrm{C} 16$ & 1.388 \\
\hline 37 & $\mathrm{C} 15$ & $\mathrm{C} 20$ & 1.427 \\
\hline 38 & $\mathrm{C} 16$ & H16A & 0.930 \\
\hline 39 & $\mathrm{C} 16$ & C17 & 1.363 \\
\hline 40 & $\mathrm{C} 17$ & H17A & 0.929 \\
\hline 41 & $\mathrm{C} 17$ & C18 & 1.360 \\
\hline 42 & $\mathrm{C} 18$ & C18A & 0.929 \\
\hline 43 & $\mathrm{C} 18$ & $\mathrm{C} 19$ & 1.397 \\
\hline 44 & C19 & H19A & 0.931 \\
\hline
\end{tabular}




\section{Conclusions}

An efficient, economic, and fast synthetic route was designed for the construction of the $\mathrm{N}$-aryl- $\mathrm{N}-(3-$ indolmethyl)acetamides incorporating the indolic core, structural analogues of some alkaloids. The acylation method is worth as a regioselective process because the variations in conditions lead to the mono- or di-acetamide. The compound characterization through different techniques gives evidence enough and strong support with regard to the success of the proposed scheme.

\section{Financial support}

The authors are grateful to the Research Center of Excellence CENIVAM (Grant COLCIENCIAS No. 4322004) for the support to the project.

\section{Conflict of interests}

The authors are in agreement with the results published in this article and claim no conflicts of interest with the same.

\section{References}

1. Sundberg RJ. The Chemistry of Indoles; San Diego: Academic Press; 1996.

2. Wynne JH, Stalick W.M. Synthesis of 3-[(1-Aryl) aminomethyl]indoles. The Journal of Organic Chemistry 2002; 67 (16): 5850-5853.

3. Molina P, Alcantara J, Lopez-Leonardo C. Regiospecific preparation of $\alpha$-carbolines andpyrimido [3, 4a]indole derivatives by intramolecular ring-closure of heterocumulene-substituted indoles. Tetrahedron. 1996; 52 (16): 5833-5844.

4. Phytochemical Dictionary. A Handbook of Bioactive Compounds from Plants,. Harborne JB, Baxter H. (Editores) London-Washington: Taylor \& Francis; 1993.

5. Snyder HR, Smith CW, Sterwart JM. Carbon-Alkylation with Quaternary Ammonium Salts. A New Approach to the Synthesis of Compounds Containing the $\alpha$-Indolemethylene Group. Journal of the American Chemistry Society. 1944; 66 (2): 200-204.

6. Brehm WJ, Lindwall HG. The preparation of Mannich bases related to Gramine. The Journal of Organic Chemistry. 1950; 15 (3): 685-687.
7. Dai HG, Li JT, Li TS. Efficient and Practical Synthesis of Mannich Bases Related to Gramine Mediated by Zinc Chloride. Synthetic Communications. 2006; 36 (13): 1829-1835.

8. a) Ke B, Qin Y, He Q, Huang Z, Wang F. Preparation of bisindolylalkanes from $\mathrm{N}$-tert-butanesulfinyl aldimines. Tetrahedron Lettetrs. 2005; 46 (10): 1751-1753.

9. Zhao JL, Liu L, Zhang HB, Wu YC, Wang D, Chen YJ. Three-Component Friedel-Crafts Reaction of Indoles, Glyoxylate, and Amine under Solvent-Free and Catalyst-Free Conditions - Synthesis of (3-Indolyl)glycine Derivatives. Synlett. 2006; (1): 96-100.

10. Jiang B, Huang Z.-G. Synthesis of á-(3-Indolyl)glycine Derivatives via Spontaneous Friedel-Crafts Reaction between Indoles and Glyoxylate Imines. Synthesis. 2005; (13): 2198-2204.

11. Shirakawa S, Kobayashi S. Carboxylic Acid Catalyzed Three-Component Aza-Friedel-Crafts Reactions in Water for the Synthesis of 3-Substituted Indoles. Organic Letters. 2006; 8 (21): 4939-4942.

12. Kouznetsov VV, Vargas Méndez LY, Tibaduiza B, Ochoa C, Montero Pereira D, Nogal Ruiz JJ, Portillo C.F, Gómez AB, Bahsas A, Amaro-Luis J. 4-Aryl (benzyl)amino-4-heteroarylbut-1-enes as Building Blocks in Heterocyclic Synthesis. 4. ${ }^{1}$ Synthesis of 4, 6-Dimethyl-5-nitro(amino)-2-pyridylquinolines and their Antiparasitic Activities. Archiv der Pharmazie. 2004; 337 (3): 127-132.

13. Kouznetsov V, Rodríguez W, Stashenko E, Ochoa C, Vega C, Rolón M, Montero Pereira D, Escario J. A, Gómez Barrio A. Transformation of Schiff Bases Derived from alpha-Naphthaldehyde. Synthesis, Spectral Data and Biological Activity of New-3-Aryl2-(alpha-naphtyl)-4-thiazolidinones and N-Aryl-N-[1(alpha-naphthyl)but-3-enyl]amines. Journal of Heterocyclic Chemistry. 2004; 41 (6): 995-999.

14. Vargas MLY, Castelli MV, Kouznetsov VV, Urbina GJM, López SN, Sortino M, Enriz RD, Ribas JC, Zacchino SA. In vitro antifungal activity of new series of homoallylamines and related compounds with inhibitory properties of the synthesis of fungal cell wall polymers. Bioorganic \& Medicinal Chemistry. 2003; 11 (7): 1531-1550.

15. Hutchins RO, Hutchins MK. Comprehensive Organic Synthesis, Oxford: Pergamon Press; 1991.

16. Kleemann A, Engel J. Pharmaceutical Substances, New York: Thieme; 1999. 
17. Evers A, Hessler G, Matter H, Klabunde T. Virtual Screening of Biogenic Amine-Binding G-Protein Coupled Receptors: Comparative Evaluation of Protein- and Ligand-Based Virtual Screening Protocols. Journal of Medicinal Chemistry. 2005; 48 (17): 5448-5465.
18. Billman JH, Diesing AC. Reduction of Schiff Bases with Sodium Borohydride. The Journal of Organic Chemistry. 1957; 22 (9): 1068-1070.

19. Layer RW. The Chemistry of Imines. Chemical Reviews. 1963; 63 (5): 489-510. 